Research.

\title{
PERCEPTION OF THE COOPERATIVE UNIT MANAGEMENT AGAINST THE UNDERSTANDING ABOUT THE FINANCIAL REPORT OF THE COOPERATIVE UNIT IN TANGERANG
}

\author{
Hamdani ${ }^{1, *}$, Triana Zuhrotun Aulia ${ }^{2}$ \\ ${ }^{1}$ Department of Management, Tangerang University of Muhammadiyah, Tangerang, Indonesia \\ ${ }^{2}$ Department of Accounting, Tangerang University of Muhammadiyah, Tangerang, Indonesia \\ hamdani_82m@yahoo.com (Hamdani), tzahrotunaulia@gmail.com (T. Z. Aulia) \\ * Corresponding author
}

Received: November 10, 2018; Accepted: December 12, 2018; Published: December 31, 2018 To cite this article: Hamdani and Triana Zuhrotun Aulia. Perception of The Cooperative Unit Management Against The Understanding About The Financial Report of The Cooperative Unit in Tangerang, The Accounting Journal of BINANIAGA, Vol. 03, No. 02, December 2018, pp. 67-74.

\begin{abstract}
This research is to find out the effect of the perception upon the understanding about the financial report of the cooperative unit in Tangerang. The research has been done at the cooperative units in Tangerang, and the samples of the research is 53 respondents who are the management of the cooperative. Variables of this research are independent variable which is the perception of the cooperative management (PPK) and dependent variable which is the understanding about the financial report (PALK) Data collection method is field survey using questionnaires, direct interview and library study. Analysis unit is the people (cooperative unit management). Method of data analysis has applied simple linear regression. Analysis equipment is applying SPSS 24.0. The perception of the cooperative unit management has positively and significantly affected the understanding about the financial report based on SAK, ETAP at the cooperative units in Tangerang. The better perception of the cooperative unit management has improved the understanding of the financial report.
\end{abstract}

Key words: perception of the management of cooperative unit, understanding about the financial report.

\section{BACKGROUND}

Cooperative unit has had an important role to develop and to improve the potential public economy in order to make the economic democracy alive. The existence of the cooperative has been supporting either national economy or global economy. In order to make the cooperative survive, it has to be supported by a competent management, effective and efficient rational, so that it will be useful for the society and its surroundings.

The city of Tangerang which is a supporting city of Jakarta has an attractive index over the average of four categories which is investment, infrastructure, public service and tourism. It has explained that Tangerang is having a big potential power to invite the investors or business people at various sectors to be involved developing the economic district (FCG, 2017). That kind of big potential should have been the bridge increasing public economy which is prior to the economic development of the cooperative business unit and micro business, small business and medium class business.

Hamdani and Triana Zuhrotun Aulia. Perception of The Cooperative Unit Management Against The Understanding About The Financial Report of The Cooperative Unit in Tangerang 
According to Online Data System at the Ministry of Cooperative and UKM in December 2017, total of the cooperative units was 153.171 units having 26.53 million active members. But this total has decreased comparing to 2016 which was 212.135 units. (2) (https:/nik.depkop.go.id/, 2017) The decreasing of the total national cooperatives is happened due to the cooperative units in Tangerang. On February 2018 total of active cooperative units was 712 units. It has decreased comparing to the data on December 2017 indicated 962 units (3) (Tanggerangnews.com.2018). This decreasing has identified the cooperative units in Tangerang are in danger circumstances. According to the Head of the Cooperative Department, Cooperative unit's administration and UKM Tangerang, Syarifudin HW has declared that this decreasing was due to the internal problems and the impact of retail business development as well as minimarket existence in Tangerang (3) (Tangerangnews.com. 2018).

The effort to succeed the Cooperative units in Tangerang is building up good perception of the members, management, controller and government. Good perception will produce a certain cooperative development. The perception of the cooperative management against the financial report based on SAK, ETAP is still weak due to lack of their competency (Wicaksono, 2013). It is a good starting point to understand the financial report. Financial report is required as the responsibility of the management in the yearly members meeting. The understanding of financial report will speed up the yearly members meeting. In order to support the yearly member meeting, it requires competent human resources who understand yearly financial report based on SAK ETAP (Setijawan and Permatasari, 2014 and Sarifah, 2012)

The understanding of financial report based on SAK ETAP for the cooperative unit management is an important one since the financial report is the responsibility information that has to be distributed to the members. The quality of financial report has been affected by few factors such as the competency of finance officers who understand the accountancy based on SAK-ETAP (Wicaksono, 2013). The Cooperative Financial Report that is prepared based on SAK-ETAP will ease the information to be understood as it is relevant, reliable, high comparative (IAI. 2016). The financial report of the Cooperative unit that is not prepared based on the applicable standard and principles will make the users misunderstood.

This research is the development of the previous research, but it has been focusing to the objects of the Cooperative units in Tangerang. The contribution of this research is able to describe the problems of Cooperative units in Tangerang.

\section{LITERATURE REVIEW AND HYPOTHESIS DEVELOPMENT}

\section{Perception of the Cooperative unit management.}

Perception is something coming up on the person's mind after seeing, listening, or having experience. General dictionary of Bahasa Indonesia is defined that perception is a feedback or direct acceptance of something, the process of someone who receive it directly thru someone's senses. (Poerwadarminta, 1976), perception is also defined as the process applied by an individual to choose, manage and study the input of the information to create a meaningful picture. This perception is not only depending on the physical attraction but also the environmental attraction and the appearance of the related individual. (Kotler, 2003 in Mirawati, 2011)

The perception of the Cooperative management is determined as the process of readiness, knowledge, the understanding of the management to comprehend the financial report of the cooperative based on SAK-ETAP. The perception indicators being used is the readiness of the implementation, understanding of accountancy information, user friendly, usefulness and financial reporting based on SAK ETAP. Perception of the Cooperative management is very important about the understanding of the financial

Hamdani and Triana Zuhrotun Aulia. Perception of The Cooperative Unit Management Against The Understanding About The Financial Report of The Cooperative Unit in Tangerang 
report based on SAK, ETAP. Eventually, good perception of the management is the key to comprehend the financial report.

\section{The Understanding of The Financial Report}

The understanding of financial report is a basic comprehension related to the Cooperative Financial Report. In the reporting, the cooperative unit has referred to the General Guidance of Cooperative Accountancy. This guideline is the guidance to direct and to prepare the Cooperative Accountancy regulating the accountancy of the Cooperative business unit upon any transaction occurred between the cooperative unit and its members or non-members and or the cooperative itself. Specifically, the Cooperative Accountancy is the system of recording systematically which figures out a transparent accountancy system and responsibly which is in accordance with the value, norms, and cooperative principles.

The Cooperative Financial Report is providing the information about the condition, performance and any changes of the Cooperative financial statement which is very useful for the strategic decision making to evolve the cooperative. The implementation of the Cooperative accountancy is still referred to the changes of the development of Financial Accountancy Standard (SAK) which refers to the International Financial Reporting Standard or IFRS. Board of the Financial Accountancy Standard, Indonesia Accountancy Association have issued the Declaration of the Withdrawal of the Financial Accountancy Standard 9 (PPSAK 8) on 8 April 2011 upon the withdrawal of the Financial Accountancy Standard 27 (PSAK 27) regarding the Accountancy of the Cooperative business unit.

The Financial Accountancy Standard which is referred to the IFRS has been classified into 2(two) classes, The Standard of Entity Financial without Public Accountability (SAK ETAP) and The Standard of General Financial Accountancy (General SAK). Cooperative is within the entity without public accountability which implements SAK ETAP. Components of the Cooperative Financial Report is described on the Regulation No.25-year of 1992 Chapter 35 regarding the balance sheet, calculation of business earnings, report of equity(capital) change, report of cash flow and financial reporting.

\section{Perception of the Cooperative Unit Management and the Understanding about the Financial Report}

Perception is defined as the understanding, interpretation and individual feedback to remember or to identify something. Perception is also defined as the process used by an individual to select, manage and interpreted the input information to create a meaningful picture. Good perception has given positive impact upon the expected target. In order to improve the understanding about financial report, a good perception is required, because bad perception of the management will make the understanding about financial report difficult. All of this is depending on the perception produced.

Setijawan and Permatasari (2014) divided the perception into the readiness of implementation, understanding of accountancy information, user friendly, usefulness and preparation of the financial report using SAK ETAP. The perception of the Cooperative unit management is very important to understand the financial report based on SAK ETAP. Good perception of the management will be the key of the understanding the financial report itself.

It is proved that the stronger readiness of perception has tended the higher implementation of SAK ETAP (Sarifah, 2012). The weaker the perception of information understanding is happened, the weaker the implementation of SAK ETAP will be (Sarifah, 2012). The perception of easy implementation has positively affected the implementation of SAK ETAP. The perception of the usefulness has positively affected the implementation of SAK ETAP. The weaker the perception of financial report is happened, the weaker the implementation of SAK ETAP will be. 
Each perception will either strengthen or weaken the implementation of SAK ETAP as the guideline of the Cooperative Financial Reporting. Therefore, first perception against the financial report is the most important thing for the management to improve their understanding about the financial report. The Description above can define the following hypothesis.

$\mathrm{H}_{1}$ : The perception of the Cooperative Management has affected the understanding about the financial report.

\section{Conceptual Research Design}

The correlation of the variables described above can be described as the following picture:

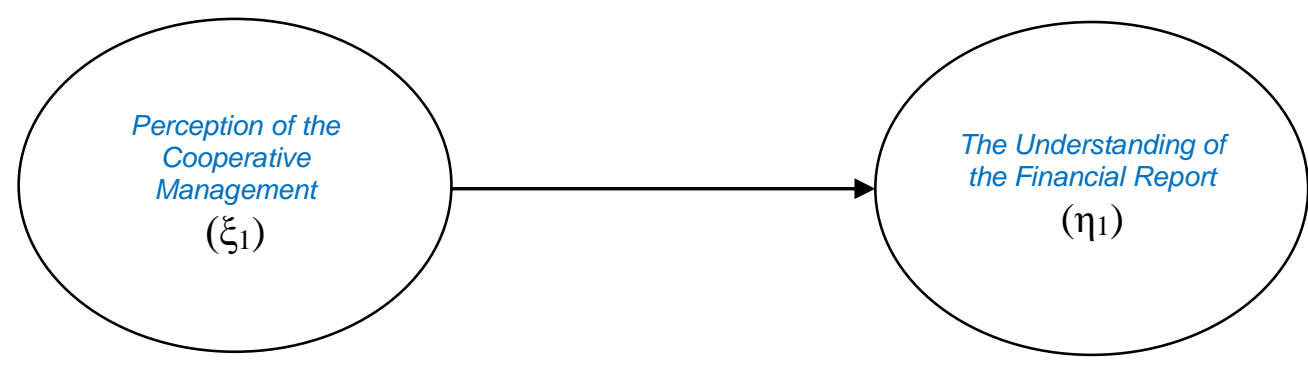

Y1.1

\section{Picture 1. Research Design}

\section{RESEARCH METHODOLOGY}

This research has applied quantitative data using the questionnaires. This research has taken place at the Cooperative units in Tangerang, using the samples of 53 respondents which is they are the management of the Cooperative. Criteria of the samples are the management of the Cooperative units in Tangerang and the Cooperative units which has not implemented yet the RAT up to 2016.

The variables of this research consist of the perception of the Cooperative management which are measured using the five indicators of Setijawan and Permatasari (2014). Variable of financial report understanding is measured using the indicator developed by Khikmah dan Yuliani (2013). Measuring the variables has applied Likert 1-5 scale. Data is collected using field survey using the questionnaires, direct interview and library study. Analysis method of this research has applied SPSS V 24.0

\section{RESULT AND DESCRIPTION OF THE RESEARCH}

\section{Result of the Research}

\section{a. Questionnaires Distribution}

Sample of the research is the Cooperative management in Tangerang. Questionnaires have been distributed to 150 respondents and the feedback is only 57 . Only 53 questionnaires can be analyzed, however, 14 questionnaires are not complete.

\section{b. Respondent Demography}

Based on the gender, there are 35 male respondents or $71 \%$. Based on the age, it is dominated by the range of age between $35-44$ or 18 to $37 \%$. Based on the experience, majority is $>10$ year about 21 respondents or $42 \%$ and

Hamdani and Triana Zuhrotun Aulia. Perception of The Cooperative Unit Management Against The Understanding About The Financial Report of The Cooperative Unit in Tangerang 
22 respondents or $45 \%$ having the background of Economy, Management, Public Administration or Business Administration.

\section{c. Result of Data Analysis}

\section{1) Descriptive Statistics}

The indicator of the readiness of the implementation SAK ETAP and the Perception of the understanding of accountancy information has been classified not good which is 3.6735 and 3.8571 , however, other indicators (perception of easiness, financial reporting, and implementation SAK ETAP) are in the scale 4 which means good perception of the Cooperative management.

The indicator of the understanding about financial reporting which is the understanding of the standard of financial report, SAK ETAP information, SAK ETAP socialization, SAK ETAP understanding and the differences of PSAK and SAK ETAP has been classified not good which is $3.8367,3.9388,3.3265$. 3.6122 and 3.3878. However, other indicators (bookkeeping and the important of bookkeeping) are on the scale 4 which means that the understanding about the financial reporting of the management is classified good.

\section{2) Instrument Test}

a) Validity Test

Test of the correlation product moment variable PPK and PALK has resulted the correlation value $(r)$ of each item $>0.25$, which means all items are valid (Basuki and Prawoto, 2016)

\section{b) Reliability Test}

Reliability test has applied Alpha Cronbach test. Result of reliability test of PPK variable has had alpha value of 0.846 and PALK variable of 0.867 . If alpha value is $>0.80$, it means that its reliability is high (alpha between $0.70-0.90$ ) explaining that all items are reliable. Since all items are valid and reliable, further analysis test can be done.

\section{3) Test of Linear Regression}

Result of data processing using SPPS 24.0 as follows:

Table 1. SPSS Output Result

\begin{tabular}{|c|c|c|c|c|}
\hline \multicolumn{5}{|c|}{ Model Summary } \\
\hline Model & $\mathrm{R}$ & R Square & Adjusted R Square & Std. Error of the Estimate \\
\hline 1 & $.688^{\mathrm{a}}$ & .473 & .463 & 5.61178 \\
\hline
\end{tabular}

\begin{tabular}{|c|c|c|c|c|c|c|}
\hline \multicolumn{7}{|c|}{ ANOVA $^{a}$} \\
\hline & & Sum of Squares & df & Mean Square & $\mathrm{F}$ & Sig. \\
\hline \multirow[t]{3}{*}{1} & Regression & 1441.224 & 1 & 1441.224 & \multirow[t]{3}{*}{45.765} & \multirow[t]{3}{*}{$.000^{\mathrm{b}}$} \\
\hline & Residual & 1606.097 & 51 & \multirow[t]{2}{*}{31.492} & & \\
\hline & Total & 3047.321 & 52 & & & \\
\hline
\end{tabular}

a. Dependent Variable: PALK

b. Predictors: (Constant), PPK 
Coefficients ${ }^{\mathrm{a}}$

\begin{tabular}{|c|c|c|c|c|c|c|}
\hline \multirow[b]{2}{*}{ Mod } & & \multicolumn{2}{|c|}{ Unstandardized Coefficients } & \multirow{2}{*}{$\begin{array}{c}\text { Standardized Coefficients } \\
\text { Beta }\end{array}$} & \multirow[b]{2}{*}{$t$} & \multirow[b]{2}{*}{ Sig. } \\
\hline & & B & Std. Error & & & \\
\hline 1 & (Constant) & 19.720 & 6.314 & & 3.123 & .003 \\
\hline & PPK & .721 & 107 & .688 & 6.765 & .000 \\
\hline
\end{tabular}

Test result of linear regression on the table above can be described as the following:

a) Determinant Coefficient is used to examine how big the effect of the perception of the Cooperative unit management has happened upon the understanding about the financial report which is applied in the regression model test, and the analysis result of this research has identified that the value of Adjusted R-Square of PALK variable is 0.463 indicating that the variety of PALK can be described by the variety of PPK which is $46.3 \%$ and the rest of $53.7 \%$ has been affected by the other variables that have not in this research model.

b) Test Regression Model is declared applicable if the significant value of ANOVA is $<0.05$. The predictor which is used as the independent variable should have been applicable. The following table has indicated the sig.value of $0.000<0.05$ which means that the model is fit and applicable for further analysis.

c) Hypothesis Test (T test). $T$ test is applied to figure out the effect of variable $X$ upon variable $Y$. The table above has indicated that the value of t-value is 6.675 and sig.value is 0.000 which means the hypothesis $(\mathrm{H} 0)$ is rejected because T count of 6.675>t-table of 2.005 and sig.value of $0.000<0.05$ which means that the Perception of the management of the Cooperative unit has affected the Understanding about the Financial Report.

d) Regression Equation has obtained PALK $=19,720+0,721$ PPK which means that the constant value is 19.720 indicating that there is not any PPK value, but PALK value is 19.720. PPK regression coefficient is 0.721 which means that there is an increasing value of 1 at PPK which will affect PALK value of 0.721 . Based on the result of regression equation, it can conclude that better perception of the Cooperative unit management will improve the understanding about the financial report.

\section{Description}

Based on the calculation test result of SPSS, it has indicated that PPK has affected PALK with the $t$ count value of $6.675>t$ table of 2.005 and sig. value of 0.000 $<0.05$ and it has been proved statistically that the Perception of the Cooperative Unit Management (PPK) has positively and significantly affected the Understanding about the Financial Report (PALK). It has explained that the hypothesis indicating that an effect of the perception of the Cooperative Unit management has happened upon the Understanding about the Financial Report which is accepted.

A good perception of the Cooperative unit management is the basic of working capital to improve the understanding about the financial report. The management of the Cooperative unit will get the understanding about financial report based on SAK ETAP if they are supported by the knowledge and well-prepared of the management. Wicaksono (2013) described that perception of the understanding about the financial report based on SAK ETAP is weak due to lack of the competency of management and other factors such as time management and manpower. Nevertheless, human resource at the Cooperative unit is not in the position to implement SAK ETAP. In

Hamdani and Triana Zuhrotun Aulia. Perception of The Cooperative Unit Management Against The Understanding About The Financial Report of The Cooperative Unit in Tangerang 
addition, since they are not ready to do it, it is the reason why the management of Cooperative unit has not implemented yet a complete SAK ETAP. Eventually, there is still lack of socialization of the practice of financial reporting complied with SAK ETAP. Obviously, the perception of the Cooperative unit Management to understand the accountancy information in the financial report is still weak.

\section{CONCLUSION AND SUGGESTION}

\section{Conclusion}

Based on the result of hypothesis test above, it is concluded that the Perception of the Management of Cooperative unit (PPK) has positively and significantly affected the Understanding about Financial Report (PALK). Better perception of the management of cooperative unit covering the readiness and knowledge will improve the understanding about the financial report based on SAK ETAP.

\section{Suggestion}

Since the sample of this research is still small which is only 53 respondents, next research can add more samples. The limitation of other researches has indicated the test result of determinant coefficient variable of the Understanding about the Financial Report (PALK) which is $0.453<0.50(50 \%)$. Nevertheless, test of the variables should have to be performed to get a better result.

Suggestion for the Government which is The Cooperative Department and UKM in Tangerang, they should have responded some findings on this research by doing an immediate accountancy training for the Cooperative units based on SAK ETAP. Socializing SAK ETAP for the management and employees of the Cooperative units is required involving IAI management, universities and accountancy practitioners of the Cooperative unit which have to be concerned about recent problems encountered by the Cooperative unit in Tangerang. For the Cooperative business units, they have to increase the financing of Cooperative business unit education prior to the socialization of the activities and Cooperative business units training based on SAK ETAP.

\section{REFERENCES}

Ghozali, I. (2014). Structural Equation Modeling Method Alternative with the Partial Least Squares. Publishing Agency Faculty of Economic Undip, Semarang.

Ghozali, I and Latan, H. (2014). Partial Least Squares (PLS) Concept, Method, and the application using Program Warppls 4.0, Publishing Agency Faculty of Economic Undip, Semarang.

Khikmah dan Yuliani. 2013. Perception of SMEs towards ETAP Financial Accounting Standards (SAK) to improve company performance, Beginner Lecturer Research, Universitas Muhammadiyah Magelang.

Kusuma, M and Budianto, $\mathrm{H}$. (2013), The Effect of the understanding the cooperative accountancy based on SAK - ETAP upon the quality of financial reporting of the cooperative unit, Cahaya Aktiva, 3 (2), pp 81-91.

Regulation of the Ministry of the Cooperative and Small to Medium class business unit number 04/Per/M.KUKM/VII/2012 - regarding the Guideline of the Cooperative Accountancy of the Ministry of Cooperative and Small and Medium business unit Republic of Indonesia. 
Regulation of the Ministry of Cooperative and Small and Medium Business Unit Number 19/PER/M KUKM/IX/2015 regarding The Arrangement of the Meeting of the Cooperative unit members.

Planning of Medium Term of the Development of the District (RPJMD) Tangerang year $2014-2018$.

Sarifah, H. (2012). The Implementation of The Accountancy based on SAK ETAP at UKP Batik Sidoarjo Village.

Setijawan, I and Permatasari, R. (2014). Analysis of the Perception of the Easy implementation and the Preception of usefulness upon the implementation of the Standard of Accountancy of the Finance Entity without Accountability of the public at the Cooperative units in Semarang, Jurnal Bisnis dan Ekonomi, 21 (2), pp 163175.

Sholihin M. dan Ratmono D. (2013). Analysis Structural Equation Modeling Partial Least Squares (PLS) with Wasppls 3.0 for the Correlation Non Linear in the Social and Business Research, CV. Andi Offcet, Yogyakarta.

Acts of the Republic of Indonesia Number 25-year 1992 regarding the Cooperative business unit.

Wicaksono, A. (2013). Perception of the members and the competency of the Cooperative unit management upon the Financial Reporting of the Cooperative unit based on SAK ETAP at KPRI' Teacher) in Talun Sub-district in Blitar District, Jurnal Riset Mahasiswa Akuntansi Universitas Kanjuruhan Malang, 1 (1).

https://nik.depkop.go.id (accessed in August 2017)

https://tangerangnews.com (accessed in August 2018)

Hamdani and Triana Zuhrotun Aulia. Perception of The Cooperative Unit Management Against The Understanding About The Financial Report of The Cooperative Unit in Tangerang 